ISSN: 0213-2060

DOI: https://doi.org/10.14201/shhme20193725172

\title{
ESCRITURA Y PODER EN CASTILLA DURANTE LA BAJA EDAD MEDIA: ESCRIBIR PARA EL GOBIERNO, ESCRIBIR PARA LA ADMINISTRACIÓN ${ }^{1}$
}

\author{
Writing and Power in Castile in the Lower Middle Ages: Writing for the Government, \\ Writing for the Administration \\ Mauricio HERRERO JIMÉNEZ \\ Depto. de Prehistoria, Arqueología, Antropología Social y CC. TT. Historiográficas. Facultad de Filosofía y Letras. \\ Universidad de Valladolid. Plaza del Campus, s/n. E-47011 VALLADOLID. C. e.: herrero@fyl.uva.es
}

Recibido: 2018-09-15

Revisado: 2019-04-07

Aceptado: 2019-11-08

RESUMEN: En el trabajo se analiza la escritura como testimonio de la evolución de la administración del gobierno y el ejercicio del poder en Castilla entre los siglos XIII y xv.

Palabras clave: Escritura; Poder; Baja Edad Media; Gobierno; Administración.

ABSTRACT: The work analyze writing as a testimony of the evolution of the administration of government and the exercise of power in Castile between the thirteenth and fifteenth centuries.

Keywords: Writing; Power; Lower Middle Ages; Government; Administration.

SUMARIO: 0 Introducción. 1 Escribir para el gobierno en Castilla durante la Baja Edad Media. 1. 1 Escritura y poder. 1. 2 Poder real, gobierno y documento. 2 Escribir para la Administración. 2. 1 Un nuevo soporte y una lengua nueva para los documentos de la administración. 2. 2 Una escritura para la administración. 3 Conclusión. 4 Referencias bibliográficas.

1 Este trabajo es resultado del proyecto de investigación «El ejercicio del poder: espacios, agentes y escrituras (siglos XI-Xv)», clave HAR2017-84718-P, financiado por el Ministerio de Economía, Industria y Competitividad de Espańa; la Agencia Estatal de Investigación y el Fondo Europeo de Desarrollo Regional de la Unión Europea. 
ESCRITURA Y PODER EN CASTILLA DURANTE LA BAJA EDAD MEDIA: ESCRIBIR PARA EL GOBIERNO, ESCRIBIR PARA LA ADMINISTRACIÓN MAURICIO HERRERO JIMÉNEZ

\section{INTRODUCCIÓN}

No es original (y no pretende serlo) la relación establecida en el título entre escritura y poder. No han sido pocos los autores que han explicado esa relación a partir de la instrumentalización de la escritura o de su aprovechamiento por parte del poder para conseguir un fin concreto, como puede ser el control del gobierno y el dominio de la administración ${ }^{2}$. Y la clave está, precisamente, no tanto en el reconocimiento de la utilidad y el provecho que la escritura tiene para el poder -que también-, cuanto en la identificación del fin con que se escribe y por qué se escribe.

La comprensión de la intención de lo escrito, el reconocimiento del propósito con que se hace, permitirá explicar la escritura entendida como acción y efecto de comunicar algo a alguien por escrito y también los medios para hacerlo. Pero será la transformación de la escritura entendida como representación de signos sobre una materia escriptoria y la evolución de sus formas o los cambios en su trazado los que manifiesten las modificaciones que se producen en el poder (entendido como gobierno de una comunidad política) y lo que implica en las relaciones entre este y aquella. La escritura, por tanto, no es solo el signo escrito; pero la escritura así entendida, como sistema de signos empleados para escribir, es también y sobre todo el asunto del que se ocupa la Paleografía, que no se ensimisma en el simple análisis de las formas y figuras de la escritura, sino que a través de su estudio penetra en todo lo concerniente a la producción y conservación de lo escrito ${ }^{3}$, en definitiva a explicar por qué se escribe y por qué se guarda con cuidado lo escrito, por qué el cuidado de su permanencia ${ }^{4}$.

\section{Escribir para el gobierno en Castilla durante la Baja Edad Media}

\subsection{Escritura y poder}

La escritura no solo importa para el poder en la Castilla de la Baja Edad Media por ser un medio de comunicación más, sino porque es una forma de permanencia que es

2 Stone, Lawrence. «Literacy and Education in England, 1640-1900». Past and Present, 1969, vol. 42, pp. 65-96, especialmente p. 84.

3 Véase Herrero Jiménez, Mauricio. «La vocación de paleógrafo de José Manuel Ruiz Asencio». En Herrero de la Fuente, Marta et ál. (coords.). Alma Littera. Estudios dedicados al Profesor José Manuel Ruiz Asencio. Valladolid: Universidad de Valladolid, 2014, pp. 317-325.

4 Herrero Jiménez, Mauricio. «El valor de los documentos reales en los procesos de la Real Chancillería de Valladolid». Espacio, Tiempo y Forma. Serie III, Historia Medieval, 2018, vol. 31, pp. 403-430, donde se aborda la cuestión de la conservación de los documentos en los archivos y las dificultades ocasionadas por la pérdida de los registros de la corona castellana en la Edad Media.

«L'Ecriture», en palabras de Hajnal, «n'est pas un facteur isolé et unique du progrés; aprés son apparition elle peut avoir un avenir tout different dans les diverses civilisations. Et pourtant, nous ne pouvons considerer simplement comme un moyen passif, accessoire, dont disposent les forces du progrés lorsque le moment de son utilisation, est venu. L'Ecriture, tout comme les autres formes de civilisation, est un moyen né de l'ensamble de la société: son avenir depend du caractère systematique de sa penetration dans la société». Véase Hajnal, Istvan. L'enseignement de l'écriture aux universités médiévales. Deuxième édition revue, corrigée et augmentée des manuscrits posthumes de l'auter, avec un album de facsimilés par Laszlo Mezey. Budapest: Maison d'Édition de l'Académie des Sciences de Hongrie, 1959, p. 9. 
ESCRITURA Y PODER EN CASTILLA DURANTE LA BAJA EDAD MEDIA: ESCRIBIR PARA EL GOBIERNO, ESCRIBIR PARA LA ADMINISTRACIÓN MAURICIO HERRERO JIMÉNEZ

reconocible, una manera de fijar la información, que su productor considera un tesoro, un arsenal de gobierno primero y de autoridad después, esencial por tanto para el poder que gobierna. Y por esencial el poder convierte la información en inaccesible.

En Las Partidas se repara claramente en esa idea de la permanencia:

El antigüedad de los tiempos, es cosa que faze a los omes oluidar los fechos pasados. E por ende fue menester, que fuesse fallada scritura, porque lo que ante fuere fecho, non se oluidasse, e supiessen los omes por ella las cosas, que eran establescidas, bien como si de nueuo fuessen fechas.

Y en los preámbulos diplomáticos medievales la imagen o representación de la permanencia y la memoria está muy presente, transmitiendo la idea de que esta última se mantiene en lo escrito, en la escritura, en el documento, que conserva el negocio jurídico en su ser y le hace estable ${ }^{6}$. Estabilidad e inaccesibilidad, dos cualidades distintivas del diploma medieval, esenciales para su productor, que soporta en ellas la memoria y la autoridad que, merced a la escritura, puede ejercerse sin los límites del tiempo y el espacio que impone la oralidad. En ese tiempo y en ese espacio ilimitado la escritura es apariencia del poder y medio para legitimarlo y ejercerlo. Y ahí está el poder de la escritura ${ }^{7}$, apreciable en las visibles inscripciones epigráficas, de naturaleza eminentemente comunicativa (y, si se quiere que sea, también propagandística) que Molina de la Torre ${ }^{8}$ ha interpretado a la luz de la teoría de la comunicación propuesta por Martín Almagro; y apreciable también el poder de la escritura en otras manifestaciones escritas como las diplomáticas, invisibles por inaccesibles. Unas y otras, e igualmente las escrituras librarias, son para el poder constituido, que retiene para sí, más allá de que le pertenezcan, los espacios gráficos, una herramienta perfecta instrumentalizada para el ejercicio del poder y las funciones gubernativas. Cuando los órganos de gobierno bajomedievales castellanos son conscientes de ello, la imagen de la permanencia y la memoria se hace más fuerte y se acrecienta por el hecho de que la escritura se hace omnipresente, tanto que, reconocido el poder de esta, el propio ejercicio de escrituración generará formas escriturarias no solo del poder sino para el poder y más concretamente para la acción administrativa, para la administración. Y en ello están las escrituras cortesana y procesal, "pensadas» para escribir los documentos generados por los órganos que se ocupan, respectivamente, de la resolución de los asuntos de gobierno y de justicia a fines de la Edad Media.

5 Las Siete Partidas del Sabio Rey Don Alfonso el IX [sic] con las variantes de más interés y con la glosa de Gregorio López; vertida al castellano y estensamente adicionada, con nuevas notas y comentarios y unas tablas sinópticas comparativas, sobre la legislación española, antigua y moderna, hasta su actual estado, por Ignacio Sanponts y Barba, Ramón Martí de Eixala y José Ferrer y Subirana. Barcelona: Imprenta de Antonio Bergnes, 1843-1844, Partida III, Título XVIII, p. 358.

6 Martín Prieto, Pablo. «Idea e imagen del rey en la diplomática medieval hispana: el valor de los preámbulos». Espacio, Tiempo y Forma. Serie III, Historia Medieval, 2016, vol. 29, pp. 453-496, especialmente pp. 464 y 483-484; Gimeno BlaY, Francisco M. "Conservar la memoria, representar la sociedad». SIGNO. Revista de Historia de la Cultura Escrita, 2001, vol. 8, pp. 275-293, especialmente pp. 281-282.

Ruiz García, Elisa. «El poder de la escritura y la escritura del poder». En Nieto Soria, José Manuel (dir.). Orígenes de la Monarquía Hispánica. Propaganda y legitimación (ca. 1400-1520). Madrid: Dykinson, 1999, pp. 275-313, especialmente p. 276.

8 Molina de la Torre, Francisco Javier. Corpus inscriptionum Hipaniae mediaevalium. 3. Valladolid (siglos X-XV). [León]: Universidad de León, 2017, pp. 27-43. 
ESCRITURA Y PODER EN CASTILLA DURANTE LA BAJA EDAD MEDIA: ESCRIBIR PARA EL GOBIERNO, ESCRIBIR PARA LA ADMINISTRACIÓN

\subsection{Poder real, gobierno y documento}

Podríamos haber elegido para el epígrafe el sustantivo archivo en lugar del vocablo documento, pero supondría aludir a una institución real que, como tal institución, no existe en Castilla hasta bien entrado el siglo xvi y rebasa los límites temporales en los que nos movemos. Es más, emplear el término documento nos va a permitir ahondar en una realidad que experimentará unas transformaciones a lo largo de los siglos bajomedievales castellanos que son consecuencia de las experimentadas en la propia administración, que, sin embargo, es incapaz de guardar no ya lo que recibe sino las copias de la documentación que expide. Y esta circunstancia dice mucho de la falta de consistencia y estabilidad en el poder real y autoridad regia'.

Sin embargo, entre los siglos XIII y Xv, momento en que la monarquía obtendrá estabilidad, se producen en la administración central castellana unos cambios extraordinarios que al final del periodo darán lugar a una normalización y perfecta regulación de la distribución y gestión de los asuntos de gobierno, que no habría sido posible sin el documento.

Y esos cambios empiezan por la propia monarquía, que desde el siglo XIII reclama como propio el gobierno y la administración del reino, como se aprecia bien en Las Partidas:

Rey tanto quiere dezir, como regidor, ca sin falla a él pertenesce el gouernamiento del reyno. E segund dixeron los Sabios antiguos, e señaladamente Aristóteles en el libro que se llama Política en el tiempo de los Gentiles el rey non tan solamente era guiador e cabdillo de las huestes, e juez sobre todos los del reyno, más aun era señor en las cosas espirituales, que estonzes se fazian por reuerencia e por honrra de los dioses, en que ellos creýan. E por ende los llamauan reyes, porque regian también en lo temporal, como en lo spiritual. E señaladamente tomo el rey nome de nuestro Señor Dios, ca assí como Él es dicho Rey sobre todos los reyes, porque dél han nome, e los gouierna, e los mantiene en su lugar en la tierra, para fazer justicia e derecho; assi ellos son tenudos de mantener, e de guardar en justicia, e en verdad a los de su señorío. E aun otra manera mostraron los Sabios, porque el rey es assi llamado, e dixeron que rey tanto quiere dezir, como regla, ca assí como por ella se conoscen todas las torturas, e se endereçan, assi por el rey son conoscidos los yerros e emendados ${ }^{10}$.

Al rey pertenece el gobernamiento, el ejercicio del gobierno, la acción de gobernar el reino. Y le pertenece por voluntad divina: «Vicarios de Dios son los reyes, cada vno en su reyno» ${ }^{11}$. Gobernar el reino en una Castilla que hasta el siglo Xv va acrecentando los espacios, el territorio conquistado; gobernar con una administración que desde el siglo XIII experimenta un crecimiento destacado, tanto que se hará necesaria la separación, en un primer momento con la creación de la Audiencia Real y del Consejo Real, de los

9 Rodríguez de Diego, José Luis. «El archivo real de la Corona de Castilla (XIII-Xv)». En Sarasa SÁNCHEZ, Esteban (coord.). Monarquía, crónicas, archivos y cancillerías en los reinos hispano-cristianos: siglo XIIIXV. Zaragoza: Institución Fernando el Católico, 2014, pp. 277-308, especialmente p. 278.

10 Las Siete Partidas del Sabio Rey Don Alfonso el IX [sic], Partida II, Título I, Ley 6, pp. 730-731.

11 Las Siete Partidas del Sabio Rey Don Alfonso el IX [sic], Partida II, Título I, Ley 5, p. 729. 
asuntos de justicia y los de gobierno, y al final del periodo la diversificación y tecnificación de cada uno de los dos ámbitos, con la aparición de diferentes órganos de gobierno y de justicia, en función del territorio o de acuerdo a la naturaleza de las materias de ambos negocios.

Esa necesidad que el rey tiene del auxilio y del consejo en las tareas gubernamentales es sancionada doctrinalmente en Las Partidas, en las que, en primer lugar, se reconoce la necesidad que el rey tiene de aconsejarse:

si todo ome se dene trabajar de auer tales consejeros, mucho más lo deue el rey fazer; porque del consejo que le dan, si es bueno, viene ende grand pro a él, e grand enderçamiento a su tierra ${ }^{12}$;

y sobre qué cosas ha de hacerlo:

todas las cosas faz siempre con consejo; mas cata ante, quién es aquel con quien te has de consejar ${ }^{13}$;

y cuándo y por quién:

todas las cosas que ome faze en su tiempo, e en su sazón, dan mejor fruto que las otras, e mayormente las que se han de fazer con consejo de omes sabidores. E por ende deue ser muy auisado aquel que quiere ayudarse del consejo, que lo tome, en ante que faga el fecho, o comience la cosa sobre que se quiere consejar; e que demande consejo sobre las cosas que pueden ser, e de que los consejeros sean sabidores de los consejar, por arte o por vso: e los consejeros deuen ser omes entendidos, e de buena fama, e sin sospecha, e sin mala cobdicia ${ }^{14}$.

El análisis que diversos autores, entre los que se encuentra Salustiano de Dios, han hecho de los textos normativos alfonsíes no les ha permitido, sin embargo, establecer la existencia de un órgano colegiado de carácter permanente, con competencias consultivas ni capacidad de decisión, en el reinado de Alfonso X, sino solo reconocer una función, la de aconsejar al rey (en materias de justicia y de gobierno y hacienda) en la corte itinerante y en las propias Cortes, que se representan como un consejo ${ }^{15}$. Pero es un consejo privado, y así seguirá siendo en las minorías de Fernando IV y Alfonso XI y en el reinado de Pedro I y hasta la entronización en Castilla de la dinastía Trastámara ${ }^{16}$.

Hasta ese momento la distribución y gestión de los asuntos de gobierno se concentra fundamentalmente en la Cancillería, organismo o lugar que en Las Partidas se entiende como aquel

do deuen aduzir todas las cartas para sellar. E aquellos que lo ouieren de ver, déuenlas catar, e las que non fueren bien fechas, déuenlas romper, e quebrantar; e las que fueren fechas derechamente, déuenlas mandar sellar. E por esto la llaman Cancellería, porque en ella se deuen

12 Las Siete Partidas del Sabio Rey Don Alfonso el IX [sic], Partida II, Título IX, Ley 5, p. 795.

13 Las Siete Partidas del Sabio Rey Don Alfonso el IX [sic], Partida III, Título XXI, Ley 1, p. 504.

14 Las Siete Partidas del Sabio Rey Don Alfonso el IX [sic], Partida III, Título XXI, Ley 2, p. 505.

15 Dios, Salustiano de. El Consejo Real de Castilla (1385-1522). Madrid: Centro de Estudios Políticos y Constitucionales, 1982, pp. 38-39.

16 Ibidem, pp. 53-63. 
ESCRITURA Y PODER EN CASTILLA DURANTE LA BAJA EDAD MEDIA: ESCRIBIR PARA EL GOBIERNO, ESCRIBIR PARA LA ADMINISTRACIÓN MAURICIO HERRERO JIMÉNEZ

quebrantar, e cancellar las cartas que fueren mal fechas; e lo que deuen guardar, es esto: que non tomen cartas de mano de otro ome, si non de escriuano, o de portero del rey ${ }^{17}$.

Oficina, pues, a la que en el texto normativo de Alfonso X se le reconocen unas funciones muy claras: la escrituración de los documentos, privilegios y cartas, y el sellado de los mismos. Tarea esta que solamente se realizaría tras la comprobación de que los diplomas estaban bien hechos y habían sido registrados.

A medida que las acciones de gobierno se tornaron más complejas y se hizo necesario un aumento de personas y organismos de administración, fueron surgiendo secretarías de las que se ocuparon hombres ajenos a la Cancillería que redactaron los documentos producidos en ellas como resultado de las actividades que tuvieran encomendadas ${ }^{18}$. De esa forma aquella única oficina, que Alfonso VII concibió para que en ella se escribieran los documentos reales y se guardara el sello real, perdió la exclusividad que tenía de producción y sellado o validación diplomática.

Y si esto se apuntaba en el reinado del rey Sabio, en el de su hijo Sancho IV es una realidad, y además de la Cancillería otras secretarías, caso del tribunal de la Corte y de la Cámara Real, expiden documentos ${ }^{19}$, y otros secretarios o escribanos del rey estarían (al menos lo estaba Juan Pérez) a cargo de los libros de la mayordomía ${ }^{20}$. En los reinados sucesivos y hasta la llegada al trono de la dinastía Trastámara se va perfeccionando la diferenciación de las secretarías, y la producción documental en cada una de ellas va siendo más abundante, pero sigue sin haber unos órganos permanentes para la resolución de las materias de justicia y de gobierno.

Órganos que serán una realidad en los reinados de Enrique II, que en las Cortes de Toro del ańo 1371 confirió carácter de institución a la Audiencia Real, para que actuara como tribunal superior de justicia en la Corte, y de Juan I, que institucionalizó el Consejo Real en las cortes de Valladolid de 1385, para que actuara como órgano consultivo permanente en las materias de gobierno que eran libradas por el rey. Dos años más tarde, en las ordenanzas de Briviesca de 1387, se estableció que el monarca no podría conceder, entre otras, tenencias ni tierras ni maravedís de juro de heredad sin consultar previamente al Consejo, así como tampoco podría otorgar cartas de perdón o de legitimación; y además se determinó que tales documentos de concesión y otorgamiento habrían de estar firmados por algunos (dos o tres) miembros del Consejo para que fueran válidos ${ }^{21}$. En los negocios que eran de exclusivo entendimiento del Consejo Real, la firma del rey evidentemente no se hacía necesaria.

Por lo dicho se entiende que pocos asuntos de gobierno y justicia, pero también asuntos de gracia, quedarán fuera del conocimiento del Consejo una vez que este fue

17 Las Siete Partidas del Sabio Rey Don Alfonso el IX [sic], Partida III, Título XX, Ley 6, p. 498.

18 Torres SAnZ, David. La administración central castellana en la Baja Edad Media. Valladolid: Universidad de Valladolid, 1982, pp. 83-86.

19 Sánchez Belda, Luis. La Cancillería castellana durante el reinado de Sancho IV (1284-1295). Madrid: Instituto Nacional de Estudios Jurídicos, 1951, pp. 51-56.

20 Ibidem, pp. 184-185.

21 Dios, Salustiano de. Gracia, merced y patronazgo real. La Cámara de Castilla entre 1474-1530. Madrid: Centro de Estudios Políticos y Constitucionales, 1993, p. 90. 
ESCRITURA Y PODER EN CASTILLA DURANTE LA BAJA EDAD MEDIA: ESCRIBIR PARA EL GOBIERNO, ESCRIBIR PARA LA ADMINISTRACIÓN MAURICIO HERRERO JIMÉNEZ

perfeccionando su funcionamiento. De suerte que en la época de los Reyes Católicos, momento final del periodo que nos interesa, en el Consejo Real se veían tanto los negocios que el rey le sometía a consulta o le comisionaba para que resolviera, como los que el propio Consejo veía por propia iniciativa o a instacia de otras instituciones, fueran estas reales, concejiles, hospitalarias o universitarias, entre otras, o personas particulares, que también acudían al Consejo en busca de resolución de los negocios que les eran propios y les afectaban. Asuntos de tal diversidad que se hace difícil la determinación de las competencias del Consejo, porque lo mismo las fue acumulando que las cedió a los órganos más especializados que se fueron creando ${ }^{22}$. En definitiva, como afirma Torres Sanz, a medida que la administración se diversificó, el Consejo fue transformándose en un órgano ejecutivo y decisorio con espacio propio y con competencias también propias ${ }^{23}$.

Las transformaciones en los órganos colegiados de gobierno mencionados, Consejo Real y Audiencia, y los cambios del órgano superior de la Hacienda castellana bajomedieval, la Contaduría mayor, han permitido afirmar a algunos historiadores del Derecho que la organización administrativa moderna se articularía más tarde en torno a ellos ${ }^{24}$. Y se podría decir más: habría sido imposible ese avance de la administración sin un cuerpo de letrados trabajando en esos órganos, dando dictámenes o disponiendo y preparando las resoluciones gubernativas ${ }^{25}$. Esta manera de gobernar, no ya del rey juez sino del rey que gobierna, y que es consciente de que para hacerlo ha de contar con órganos colegiados y con un cuerpo de letrados que trabajan en una administración más tecnificada, tiene su correspondencia en una mayor produccion documental, en el surgimiento de nuevos tipos diplomáticos, en la aparición del expediente y en una mutiplicación de la escritura para la administración y de la administración, y, por último, en las transformaciones gráficas de la misma.

La ampliación de competencias gubernativas será la causa de la aparición de nuevos tipos diplomáticos, como lo es el desarrollo y ampliación de las funciones esenciales del soberano definidas en Las Partidas, a saber: la elaboración de las leyes, la administración de justicia y el otorgamiento de mercedes, a las que se suma el «gouernamiento del reyno». El aumento de esta función diversifica los negocios, aumenta la burocracia y la producción de documentos. El mayor número de estos impulsa a abreviar el procedimiento administrativo y a simplificar el modo de hacer los documentos y los documentos mismos. Y esto se logra con tenores diplomáticos más sencillos, eliminando o aligerando las partes formularias rutinarias y las que resultan superfluas para la administración, a pesar de que puedan evocar y acentúen la memoria ${ }^{26}$, tanto divina como real. De ahí que las invocaciones monogramáticas se transformen a lo largo del periodo en cruces sencillas y desnudas, los preámbulos y las fórmulas retóricas vayan poco a poco desapareciendo,

22 Dios, El Consejo Real de Castilla (1385-1522), p. 335.

23 Torres Sanz, La administración central castellana en la Baja Edad Media, pp. 210-211.

24 Ibidem, pp. 63-64.

25 Rodríguez de Diego, José Luis. «Evolución histórica del expediente». Anuario de Historia del Derecho Español, 1998, vol. LXVIII, pp. 475-490, especialmente p. 481.

26 Rodríguez, Ana. «La preciosa transmisión. Memoria y curia regia en Castilla en la primera mitad del siglo xiI». En Martínez Sopena, Pascual y Rodríguez, Ana (eds.). La construcción medieval de la memoria regia. Valencia: Universidad de Valencia, 2011, pp. 293-322, especialmente p. 297. 
ESCRITURA Y PODER EN CASTILLA DURANTE LA BAJA EDAD MEDIA: ESCRIBIR PARA EL GOBIERNO, ESCRIBIR PARA LA ADMINISTRACIÓN MAURICIO HERRERO JIMÉNEZ

incluso de los documentos más solemnes, a excepción de los privilegios rodados que perviven hasta el reinado de los Reyes Católicos; de ahí que se impongan las expresiones concretas de negocios administrativos y jurídicos, para que quede claro en qué medida se crea, se modifica o se extingue un derecho o una obligación ${ }^{27}$.

Evidentemente, en esta evolución hay que contemplar la destacada presencia de laicos con formación jurídica en las cancillerías reales que van a hacer del documento sobre todo un instrumento al servicio de la administración, que precisa de personal no de alta posición social, sino con una formación y con una preparación intelectual adecuadas ${ }^{28}$. Sirva de muestra la participación de Fernán Sánchez de Valladolid en la cancillería de Alfonso XI y en el Consejo del rey, aún no real, en el que deja testimonio de su talla como administrador, que continúa en el reinado de Pedro I, puesto que entonces será no solo canciller mayor sino oidor de la Audiencia y miembro del Consejo ${ }^{29}$. Y como él, un siglo después Fernán Díaz de Toledo, secretario del Consejo Real, jurista y redactor, profundo conocedor del Derecho vigente y que desarrolló además una sobresaliente actividad notarial. Iguales a ellos, aunque no añadamos más nombres, en los siglos de la Baja Edad Media hallamos hombres en la Cancillería real bien formados en estudios jurídicos, universitarios que se encargaron de la redacción de instrucciones y formularios que tranformaron la realidad diplomática ${ }^{30}$, que hubo de acomodarse necesariamente a la nueva realidad social y política.

Tan destacada como la sustitución a lo largo de los siglos XIV y xv de unos tipos diplomáticos, cartas plomadas, cartas abiertas y mandatos entre ellos, por otros como provisiones reales, albalaes, cartas misivas, cartas reales de merced, cartas de privilegio, cartas de privilegio y confirmación y cédulas reales ${ }^{31}$, es la aparición del expediente, que trastoca y transforma la realidad del documento simple en documento compuesto. Composición en la que cada una de sus partes no tiene sentido si se contempla de forma independiente y aislada. No pueden entenderse las partes de un todo documental que resulta de un prodecimiento administrativo y una acción de gobierno continuada,

27 Ibidem, p. 301.

28 González Crespo, Esther. «Organización de la cancillería castellana en la primera mitad del siglo XIV». En la España Medieval, 1986, vol. 8, pp. 447-470, especialmente p. 470.

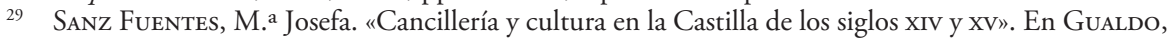
G. Cancelleria e cultura nel Medio Evo. Comunicazioni presentate nelle giornate di studio della Commissione. Stoccarda, 20-30 agosto 1985. Città del Vaticano: Archivio Segreto Vaticano, 1990, pp. 187-199, especialmente pp. 191-193.

30 Ibidem, pp. 194-199.

31 Sobre diplomática de la Baja Edad Media pueden verse, entre otros: Floriano Cumbreño, Antonio C. Curso general de Paleografía y Paleografía y Diplomática españolas. Oviedo: Universidad de Oviedo, 1946, pp. 506-549; García Oro, José. "Clasificación y tipología documental». En Riesco Terrero, Ángel (ed.). Introducción a la Paleografía y a la Diplomática General. Madrid: Síntesis, 1999, pp. 207-231; Marín Martínez, Tomás y Ruiz Asencio, José Manuel. Paleografia y Diplomática. Madrid: UNED, 1991, 5. a ed., pp. 57-91; SAnz Fuentes, M. ${ }^{a}$ Josefa. "Tipología documental de la Baja Edad Media castellana. Documentación real». En Archivistica. Estudios Básicos. Sevilla: Diputación Provincial de Sevilla, 1981, pp. 239-256; Ostos Salcedo, Pilar y Sanz Fuentes, M. ${ }^{a}$ Josefa. "Corona de Castilla. Documentación Real. Tipología (1250-1400)». En Diplomatique royale du Moyen Âge XIIT-XIV siècles. Porto: Faculdade de Letras, 1996, pp. 239-279. 
que se explica porque la administración y los órganos colegiados de gobierno son estables y permanentes. La permanencia está ahora no solo en la escritura simple, en el documento suelto, que también y siempre, sino en el conjunto documental. Una nueva realidad que es testimonio de una forma de resolución de los negocios de gobierno en el Consejo Real a partir de 1432, cuando queda consagrado en las cortes de Zamora como procedimiento ${ }^{32}$, en el que se reconocen las fases del mismo: iniciación, deliberación y acuerdo y libramiento, que concluye con la escrituración de un documento dispositivo, fuera este una provisión o una cédula real, y su resgitro. Despacho y libramiento que se encargaba al mismo escribano que había recibido la petición ${ }^{33}$.

\section{ESCRIBIR PARA LA ADMINISTRACIÓN}

El hombre pasó del otro a este lado de la historia porque halló en la escritura una manera de conservar y transmitir mediante símbolos las palabras habladas, que a su vez lo eran de la denominada por Aristóteles experiencia mental ${ }^{34}$. Pero la escritura, como descubrió Platón, es silencio y es voz. Silencio porque, de acuerdo con lo que Emilio Lledó afirma, no hay un detrás de las palabras escritas. Los signos, los símbolos no son nada y descubrir lo que comunican, la memoria, la experiencia, solo es posible hacerlo cuando se leen y por quien los le ${ }^{35}$. Y desde luego nadie escribe por escribir, pero saber por qué lo hace requiere preguntar a la escritura; sabiéndolo hacer, esta responde a las interrogaciones de cada presente ${ }^{36}$. De otra manera la escritura únicamente nos mostrará su soledad, el olvido de su origen, también el de la letra que, y vuelvo a Lledó, «se aplasta sobre la lisa superficie de la materia que la sustenta ${ }^{37}$.

Pues bien, en este diálogo que la escritura permite con el pasado y en el que el filósofo hace unas preguntas en búsqueda de unas respuestas y el historiador otras, el estudioso de la escritura entendida como representación de signos, busca en sus formas y en las transformaciones del trazado las razones de la escritura. Y leer las formas, como se hace desde la Paleografía, de la escritura gótica castellana de la Baja Edad Media no solo nos permite acceder al contenido de los textos sino conocer cuándo, cómo, quién y por qué escribió los documentos, más allá de que estos puedan considerarse como elementos de la Historia Social de la Cultura Escrita ${ }^{38}$ y se les pueda entonces hacer otras preguntas y hallar otras respuestas, no menos válidas las unas que las otras, nunca, creo, excluyentes, sino complementarias.

32 Dios, El Consejo Real de Castilla (1385-1522), p. 429.

3 Ibidem, pp. 431-449.

34 Gelb, Ignace J. Historia de la escritura. Madrid: Alianza Editorial, 1991, p. 33.

35 LLedó, Emilio. El silencio de la escritura. 2. ${ }^{\text {a }}$ ed. Madrid: Espasa, 1999, pp. 157.

36 Ibidem, p. 81.

37 Ibidem, p. 30.

38 Sierra Macarrón, Leonor. «La escritura y el poder: el aumento de la producción escrita en Castilla y León (siglos X-XIII)». SIGNO. Revista de Historia de la Cultura Escrita, 2001, vol. 8, pp. 249-274, especialmente p. 250. 


\subsection{Un nuevo soporte y una lengua nueva para los documentos de la administración}

Los documentos reales (las escrituras como acción y efecto de comunicar algo y el medio para hacerlo) en la Castilla bajomedieval, frente a lo que ocurría en las cancillerías de la Alta y Plena Edad Media, se escribieron, como se hizo en estas, como «aueriguamiento de prueua» y se sellaron, así se establecía en Las Partidas, "con sello de rey»" cuando fue necesario. Y lo fue en el caso de los privilegios («ley que es dada, o otorgada del rey apartadamente a algún lugar, o algún ome, para fazerle bien, e merced $\left.{ }^{40}\right)$, que se sellaron con sello de plomo pendiente de hilos de seda («por dar a entender que es dado para ser firme e estable por siempre» ${ }^{41}$ ), y de las cartas plomadas "que non llaman preuillejos», pero en las que se hace constar que el rey «da tal heredamiento, o otorga tal cosa, o que faze tal quitamiento, o franqueza; o si fiziere postura, o auenencia ${ }^{42}$. Pero si se quiere que el bien y la merced del privilegio sea firme por siempre, se hace necesario escribir el documento en un soporte que lo permita, y ese es el pergamino. De otra manera es suficiente el papel:

E las que deuen ser de pergamino de paño, son estas: assí como las que dan para sacar cosas vedadas del reyno; o las otras que van de mandamientos a muchos concejos, que les embia mandar el rey, o de recabdar algunos omes, o de cosechas de marauedis del rey, o de guiamiento: todas estas deuen ser en pergamino de paño, o otras, de qual manera quier que sean, semejantes dellas ${ }^{43}$.

El pergamino, amén de privilegios y cartas plomadas se utilizará también en cartas selladas con sello de cera pendiente:

E estas son de muchas maneras; que las vnas fazen en pergamino de cuero, e las otras en pergamino de paño. Pero departimiento ha entre las vnas e las otras: ca las vnas deuen ser fechas en pergamino de cuero, assi como quando el rey da alguna merindad, o alcaldía, o alguaziladgo, o judgado, o juradería; o quita de pecho, o de portadgo para en su vida; o si perdona el rey a alguno, que le aya de dar carta; o de arrendamiento que faga con él, o con otro por su mandado; o de cuenta que le ayan dada; o de postura de pleytos, o de auenencias de contiendas, o de otras cosas que han los ricos omes entre sí, o otros omes, de pleytos que fazen algunos con el rey, de lauores, o de otras cosas que le ayan de guardar en su tierra, o en su señorio; o de las cartas que da el rey a algunos, que anden saluos, e seguros por su tierra con sus ganados, e con sus cosas; o de peticiones que anden por sus reynos: todas estas, o otras que les semejen, deuen ser escritas en pergamino de cuero, assi como diximos ${ }^{44}$.

Toda una intencionalidad en la designación de los soportes de la escritura. Y en la sustitución del pergamino por el papel y en la cada vez más abundante presencia de este en la cancillería, y sobre todo en los órganos colegiados de gobierno, se muestran de una manera evidente los cambios en la administración, más papelera, nunca mejor dicho, y

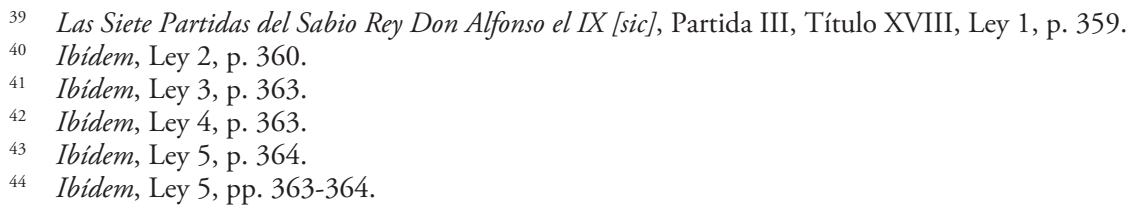


ESCRITURA Y PODER EN CASTILLA DURANTE LA BAJA EDAD MEDIA: ESCRIBIR PARA EL GOBIERNO, ESCRIBIR PARA LA ADMINISTRACIÓN MAURICIO HERRERO JIMÉNEZ

en una acción documental que, ajustada y conformada a esa administración, evoluciona desde el siglo XIII hasta los años finales del siglo XV, y se hace más continua y más eficiente. La continuidad requiere una mayor producción documental y esta hace a la actividad administrativa más eficaz; pero nada de ello hubiera sido posible sin el papel, un soporte más abundante y por tanto más barato. El papel, por tanto, multiplica la escritura, multiplica la información, multiplica la administración ${ }^{45}$; y esta administración multiplicada produce un número de documentos (que nada tiene que ver con la elaboración de las cancillerías reales de la Alta y Plena Edad Media) y conoció unos usos continuados novedosos en el reinado de Alfonso X, uno de los cuales fue, como señala Marina Kleine, «el uso del papel y del sello de cera placado en la confección de documentos de carácter transitorio» ${ }^{46}$. Usos que fueron más comunes en el reinado de Sancho IV, en cuyos libros de cuentas consta que se destinaba a la adquisición de papel una cantidad tres veces superior a la destinada a la compra de pergamino ${ }^{47}$. Inversión que no dejó de acrecentarse, porque este último se reservó para los documentos más solemnes y que eran expresión de las funciones que en el Fuero Real, el Espéculo y Las Partidas se entendían como esenciales del soberano, y que no eran otras que elaborar leyes, administrar justicia y otorgar gracias y mercedes, que no dejaba de ser entendida como una forma de hacer justicia, de otorgar recompensas en función de los servicios prestados o de imponer penas por las faltas cometidas ${ }^{48}$.

Y si el soporte es uno de los elementos que permite advertir el anhelo de permanencia, de estabilidad, de solemnidad, de perpetuación de la memoria de lo escrito en el pergamino, frente a la sobriedad, la sencillez y la utilidad del papel, la lengua será igualmente otra de las partes constitutivas de los documentos que permita comprender, como lo hará la escritura, la revolución procedimental y diplomática que trajo el aumento de la administración bajomedieval castellana.

La sustitución del latín por el castellano se explica además y también por el reconocimiento de una realidad: la imposición del castellano fuera de la cancillería. Reconocimiento que llevó a la oficina regia de expedición de documentos de Fernando III a iniciar el empleo del castellano en la redacción de los documentos, o a que el propio rey ordenara escriturar la parte dispositiva del Fuero de Córdoba, cuando se lo concedió a la ciudad el 3 de marzo de 1241, «in uulgari ydiomate» ${ }^{49}$. Lo hizo con la seguridad de que se

45 Menant, François. "Las transformaciones de la escritura documental entre los siglos XII y XIII». Traducción de Pascual Martínez Sopena, revisada por Miguel Calleja Puerta. Edad Media. Revista de Historia, 2015, vol. 16, pp. 33-53, especialmente p. 40.

46 Kleine, Marina. "Los orígenes de la burocracia regia en Castilla: la especialización de los oficiales de Alfonso X y Sancho IV». e-Spania. Revue Interdisciplinaire d'Études Hispaniques Médiévales et Modernes, 2015, vol. 20, pp. 1-28, especialmente p. 26.

47 García Díaz, Isabel y Montalbán Jiménez, Juan Antonio. «El uso del papel en Castilla durante la Baja Edad Media». En Actas del VI Congreso Nacional Historia del papel en España. Buñol (Valencia), 23-25, junio de 2005. Valencia: Conselleria de Cultura, Educació i Esport, 2005, pp. 399-418, especialmente p. 415

48 Dios, Salustiano de. «El ejercicio de la gracia regia en Castilla entre 1250 y 1530 . Los inicios del Consejo de la Cámara». Anuario de Historia del Derecho Español, 1990, vol. 60, pp. 323-352.

49 Mellado Rodríguez, Joaquín. «El fuero de Córdoba: edición crítica y traducción». Arbor, 2000, vol. 654, pp. 191-232, especialmente p. 192. La tendencia a escribir en romance los documentos notariales es anterior, como advierte Menéndez Pidal, que la sitúa en el último tercio del siglo XII. Véase Menéndez Pidal, Ramón. Orígenes del español. 6. a ed. Madrid: Espasa Calpe, 1968, p. IX; Fernández Ordóñez, Inés. «La lengua de los documentos del rey: del latín a las lenguas vernáculas en las cancillerías regias de la Península 
facilitaría su comprensión a una población heterogénea que iría ocupando cada vez más espacios tras la victoria en las Navas de Tolosa en 1212, y que tanto en la lengua hablada como en la escrita halló en el romance una forma ordinaria y corriente de comunicación. El paso estaba dado y la lengua romance castellana fue adoptada por la administración para la redacción de unos documentos que tenían que entender los súbditos y naturales del reino ${ }^{50}$. Y en ese paso no puede ignorarse tampoco ni el cambio producido en la cancillería a la muerte de Juan de Soria en 1246, puesto que a partir de entonces el uso del romance pasa del $45 \%$ a más del $80 \%$, ni el tiempo transcurrido entre el 28 de agosto de ese año, 1246, última aparición de Juan de Soria, y el 16 de febrero de 1249, en que se menciona a un nuevo canciller, el obispo electo de Jaén, Pedro, puesto que en esos dos años largos el castellano se enseñorea por la cancillería y acabará imponiéndose en el reinado de Alfonso X, de cuya oficina regia de expedición de documentos solo salen documentos en esta lengua, salvo los que se enviaron a otros reinos ${ }^{51}$.

Evidentemente, el uso del romance en la cancillería de Fernando III fue progresivo, pasó del 8,1\% en fechas anteriores a la unión de Castilla y León en 1230 y desde 1217 , al 16,50\% entre la fecha de la unificación y 1240, al 45\% en el lustro que va de 1241 a 1245 , y a una progresión cada vez mayor hasta la muerte del rey Santo en 1252, momento en que el porcentaje alcanza el 81,4\%. En el reinado de Alfonso X, entre 1252 y 1284 , el número de documentos redactados en romance alcanza cifras muy próximas al $100 \%$. Romance además castellano, que, merced a la corroboración de Fernando III primero y Alfonso X después, se impuso en perjuicio del gallego y del asturleonés ${ }^{52}$.

Pero, al igual que ocurría con el soporte, el castellano se empleará primeramente en documentos que se expiden de forma rápida, poco protocolarios, porque contienen negocios con un valor administrativo no solo evidente sino perecedero, poco durable. Y puesto que no tuvo fronteras cancillerescas, no podía haberlas, para la lengua, los documentos solemnes se escribirían muy poco después también en castellano, y como ellos los textos normativos ${ }^{53}$.

\subsection{Una escritura para la administración}

Si Alfonso X supo ver, como afirma Inés Fernández Ordóñez, la magnitud, la fuerza, el potencial político del castellano, y de ello se sirvió ${ }^{54}$, la escritura vivió desde el siglo XIII al XV unas transformaciones que se explican sin necesidad de ningún impulso, sino por la evolu-

Ibérica». En MArtínez Sopena y Rodríguez (eds.), La construcción medieval de la memoria regia, pp. 323362, especialmente pp. 329-330, defiende la redacción castellana del Fuero de Córdoba como una posible práctica de redacción primera en romance de los textos que más tarde se volvían al latín.

50 MacDonald, Robert A. «El cambio del latín al romance en la Cancillería real de Castilla». Anuario de Estudios Medievales, 1997, vol. 27, pp. 381-413, especialmente pp. 406-408; Ostos Salcedo, Pilar. "Cancillería castellana y lengua vernácula: su proceso de consolidación». Espacio, Tiempo y Forma. Serie III, Historia Medieval, 2004, vol. 17, pp. 471-484.

51 Fernández Ordóñez, «La lengua de los documentos del rey », pp. 330.

52 Ibidem, pp. 326-331.

53 Ibidem, pp. 328-329.

54 Ibidem, p. 352. 
ESCRITURA Y PODER EN CASTILLA DURANTE LA BAJA EDAD MEDIA: ESCRIBIR PARA EL GOBIERNO, ESCRIBIR PARA LA ADMINISTRACIÓN MAURICIO HERRERO JIMÉNEZ

ción de la administración, la multiplicación de la producción documental y los cambios en la resolución de negocios y en los procedimientos administrativos. Los reyes, y lo veremos al final del período, solo pudieron sancionar una realidad que se había impuesto sin necesidad de normas, y se había impuesto de tal manera que los límites, las diferencias entre las grafías de los documentos públicos y de los documentos privados se estrecharon hasta desaparecer en el siglo XV. Y en Castilla, se puede decir sin temor a errar, la escritura se hace una; y se hace una sobre todo cuando la mano, pública o privada, escribe deprisa y hace letra cursiva ${ }^{55}$.

En la cancillería de Fernando III, y será una constante hasta el final del periodo que nos ocupa, se van a escribir los documentos solemnes, los de valores jurídicos estables, en buena letra (y en pergamino, y en latín hasta el momento que ya conocemos): la escritura de privilegios.

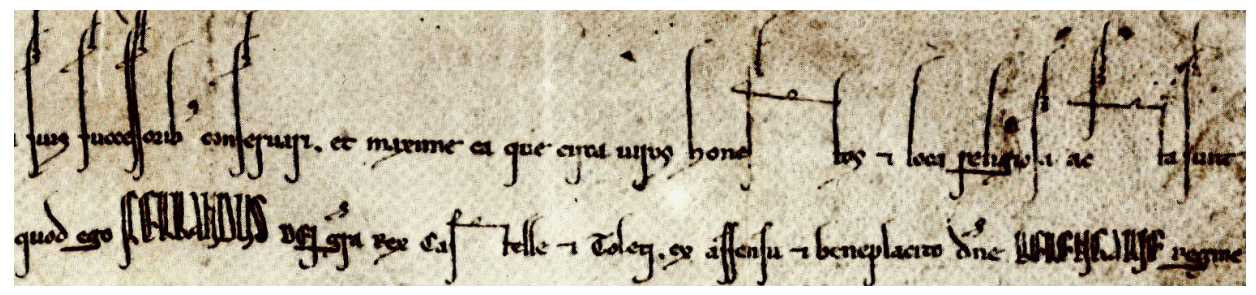

FIgURA 1.1218, noviembre, 28. Fragmento de privilegio de Fernando $\mathrm{III}^{56}$. Escritura deprivilegioprimitiva.

55 Sobre las góticas castellanas pueden verse, entre otros, Millares Carlo, Agustín y Mantecón, José Ignacio. Álbum de Paleografía Hispanoamericana de los siglos XVI y XVII. I. México: Instituto Panamericano de Geografía e Historia, 1955, pp. 41-46; Millares Carlo, Agustín, con la colaboración de José Manuel Ruiz Asencio. Tratado de Paleografía española. I. Texto. Madrid: Espasa Calpe, 1983, pp. 166-173, 193-202 y 221-236; Marín Martínez, Tomás y Ruiz Asencio, José Manuel. Paleografía y Diplomática. 1. 5.a ed. Madrid: UNED, 1991, pp. 323-346; Ídem. Paleografía y Diplomática. 2. 5.a ed. Madrid: UNED, 1991, pp. 3-35; Sánchez Prieto, Ana Belén y Domínguez Aparicio, Jesús. «Las escrituras góticas». En Riesco Terrero, Introducción a la Paleografía y a la Diplomática general, pp. 111-147; Romero Tallafigo, Manuel; Rodríguez Liáñez, Laureano y Sánchez González, Antonio. Arte de leer escrituras antiguas. Paleografía de lectura. 3. a ed. Huelva: Universidad de Huelva, 2003, pp. 64-65; Cuenca Muñoz, Paloma. «La escritura gótica cursiva castellana: su desarrollo histórico». En Galende Díaz, Juan Carlos (dir.). III Jornadas Cientificas sobre Documentación en época de los Reyes Católicos. Madrid: Universidad Complutense, 2004, pp. 23-34; Calleja Puerta, Miguel y Sanz Fuentes, M. a Josefa (coords.). Las escrituras góticas desde 1250 hasta la imprenta. Oviedo: Universidad de Oviedo, 2010; Ostos Salcedo, Pilar. "Las escrituras góticas hispanas. Su bibliografía». En Calleja Puerta y Sanz Fuentes (coords.), Las escrituras góticas desde 1250 hasta la imprenta, pp. 17-49; SANZ Fuentes, M.a Josefa. «La escritura gótica documental en la Corona de Castilla». En Calleja Puerta y Sanz Fuentes (coords.), Las escrituras góticas desde 1250 hasta la imprenta, pp. 107126; Herrero JimÉNez, Mauricio. «La escritura hispano-gótica: la escritura gótica documental castellana (siglos xiII-XviI)». En Galende Díaz, Juan Carlos; Cabezas Fontanilla, Susana y Ávila Seoane, Nicolás (coords.). Paleografía y escritura hispánica. Madrid: Síntesis, 2016, pp. 171-199. No hemos querido, para no considerar cuestiones que se alejan de la intención de este trabajo, entrar en el complejo asunto de la nomenclatura de las escrituras góticas en general y de las góticas castellanas en particular. Pero en algunas de las páginas de los trabajos citados encontrará el lector información valiosa sobre ello. Igualmente, para simplificar un asunto tan complejo, hemos optado por aceptar una terminología (propuesta por Millares Carlo y Ruiz Asencio) que no ofrece dificultad y que, entendemos, no trastoca el imaginario gráfico de los profesionales de áreas científicas diferentes al área de Ciencias y Técnicas Historiográficas.

56 Imagen tomada de Millares Carlo, Tratado de Paleografía española. II. Láminas, doc. 161. 
ESCRITURA Y PODER EN CASTILLA DURANTE LA BAJA EDAD MEDIA: ESCRIBIR PARA EL GOBIERNO, ESCRIBIR PARA LA ADMINISTRACIÓN MAURICIO HERRERO JIMÉNEZ

El nombre lo dice todo. Una escritura, pues, para los diplomas (no solo privilegios) en los que se da cuenta de la concesión de bienes y mercedes, heredamientos, quitamientos y franquezas, como se establecerá después en Las Partidas, sellados con sello de plomo para mayor firmeza y estabilidad, aunque en la cancillería del rey Santo esta escritura de privilegio sea aún un tanto primitiva.

Para los otros documentos en pergamino, pero también en papel, porque ya en la cancillería fernandina se empleó para los documentos menores el nuevo soporte ${ }^{57}$, entre ellos el mandato, documento del que Julio Gonzalez destaca su pequeñez y temporalidad, y que la cancillería utilizó para comunicar disposiciones de gobierno, concesión de exención de portazgos y ordenes concretas en general ${ }^{58}$, se emplea una escritura documental más rápida. También se empleó esta en la redacción de cartas abiertas, con disposiciones que debían ser de dominio público y que comunicaban mercedes con fecha de caducidad corta, caso de concesiones de libertades de pasto o exención de portazgo ${ }^{59}$, entre otros.

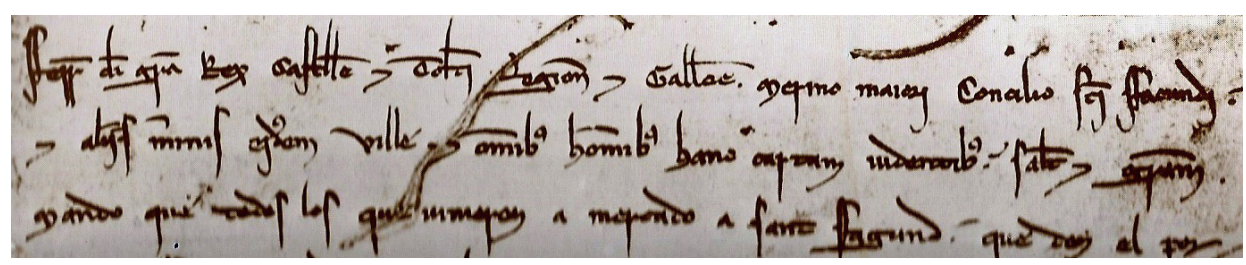

Figura 2. 1231, octubre, 21. Fragmento de mandato de Fernando III ${ }^{60}$. Escritura gótica cursiva.

Esa dualidad gráfica en los documentos de la cancillería, que tiene su correlación en los tipos diplomáticos, solemnes o no solemnes, se acentuará en el reinado de Alfonso X, a medida que la producción diplomática se acrecienta y se produce una especialización del personal de la cancillería y un acrecentamiento de su número, como ha estudiado Marina Kleine ${ }^{61}$.

57 González, Julio. Reinado y diplomas de Fernando III. I. Estudio. Córdoba: Publicaciones del Monte de Piedad y Caja de Ahorros, 1980, p. 512, donde refiere su uso en un mandato de 12 de marzo de 1252. Para una aproximación a los usos de la cancillería de Fernando III pueden verse, entre otros: Ostos Salcedo, Pilar. «La cancillería de Fernando III, Rey de Castilla (1217-1230): una aproximación». Archivo Hispalense, 1994, vol. 77, pp. 59-70; López Gutiérrez, Antonio J. «La cancillería de Fernando III, Rey de Castilla y León (12301253): notas para su estudio». Archivo Hispalense, 1994, vol. 77, pp. 71-82; Camino Martínez, M. ${ }^{a}$ Carmen del. «La escritura documental en el reinado de Fernando III». Archivo Hispalense, 1994, vol. 77, pp. 83-88.

58 González, Reinado y diplomas de Fernando III. I. Estudio, p. 547.

59 Ibidem, p. 528.

60 Imagen tomada de Millares Carlo, Tratado de Paleografía española, II. Láminas, doc. 162.

61 KleIne, Marina. La cancillería real castellana durante el reinado de Alfonso X (1252-1284): una aproximación prosopográfica (Tesis doctoral), Sevilla, 2012, pp. 214-226. Véanse sobre la cancillería de Alfonso X: López Gutiérrez, Antonio J. «La tradición documental en la cancillería de Alfonso X». Historia. Instituciones. Documentos, 1992, vol. 19, pp. 253-266; López Gutiérrez, Antonio J. «Registros y registradores en la cancillería de Alfonso X». Estudis Castellonencs, 1994-1995, vol. 6, pp. 709-720; López Gutiérrez, Antonio J. "Oficio y funciones de los escribanos en la cancillería de Alfonso X». Historia. Instituciones. Documentos, 2004, vol. 31, pp. 353-368; López Gutiérrez, Antonio J. «La génesis documental en la Cancillería Real de Alfonso X». Documenta \& Instrumenta, 2016, vol. 14, pp. 77-116. 
ESCRITURA Y PODER EN CASTILLA DURANTE LA BAJA EDAD MEDIA: ESCRIBIR PARA EL GOBIERNO, ESCRIBIR PARA LA ADMINISTRACIÓN MAURICIO HERRERO JIMÉNEZ

El crecimiento documental y la mayor escrituración tendrá una evidente consecuencia: obligará a trazar más rápidamente la escritura, y aparecerá en los documentos de cancillería la escritura gótica cursiva, próxima a la llamada escritura de albalaes y prácticamente la misma en la década de los setenta y ochenta del siglo XIII. Una escritura alejada de la solemne letra de privilegios. Pensada esta para la transmisión de la memoria intemporal, que trasciende el tiempo porque las gracias y mercedes regias se piensan, se conciben para que sean permanentes, y muchas lo fueron hasta la desamortización.

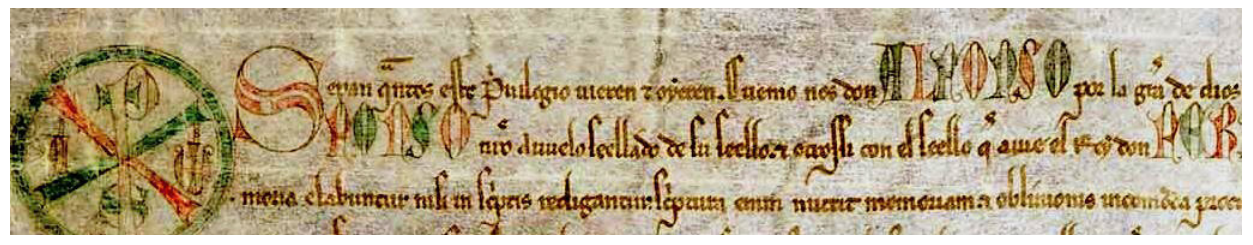

Figura 3. 1270, junio, 7. Fragmento de privilegio rodado de Alfonso X. Letra de privilegio.

Larga vida para una escritura ideada para armar una memoria larga. Y se halló la mejor escritura que podía pensarse, de letra exclusiva, que se acompańa con decoraciones extraordinarias además, entre ellas las del crismón y el signo rodado cuando el privilegio lo fue. En fin, una escritura solemne para un diploma que también lo era.

Los ejemplares más extraordinarios de esta escritura los encontramos en los documentos solemnes de la cancillería de Alfonso X, y seguirá empleándose hasta el reinado de Alfonso XI, cuando se aprecia la evolución de la escritura de privilegio, en la década de 1330, hacia una letra cercana a la «redonda de libros».

Pienso que no es caprichosa la evolución y que se ha de relacionar con el avance de la escritura cursiva, que, como después diremos, se redondea, nunca mejor dicho. La redondez y la reducción de los astiles y caídos de la escritura cursiva están provocadas porque el trazado de la letra se hace dentro o lo más ajustado posible al espacio de un sistema bilineal de escritura, lo que permite, si se busca o se pretende, ser más rápido al «tirar» la escritura. Todo lo rápido que precisa una administración cada vez mejor armada, más tecnificada y más burocrática.

Esa forma de escribir influiría en el trazado de la escritura solemne, aunque en este caso no por necesidad, porque no se requiere escribir deprisa en estos diplomas, sino por influencia estética. Sea como fuere, lo cierto es que los privilegios se escribirán a partir de la década de 1330 y hasta el último tercio del siglo xv en una «redonda de libros» o gótica redonda (textualis rotunda), que en el reinado de los Reyes Católicos y hasta casi la mitad del siglo XVII evoluciona, por las mismas razones estéticas y por una adaptación mayor aún al sistema bilineal, a una gótica que Millares definió como muy redondeada, y que Muñoz Rivero denominó gótica redonda de juros, con letras de cuerpo más grande y en las que los astiles y caídos apenas sobrepasan el espacio de la caja de renglón.

Para los documentos no solemnes, los empleados en los negocios de adminitración, se usan escrituras también menos solemnes, góticas siempre, durante un corto periodo de tiempo una gótica documental, pero a partir del reinado de Alfonso X y hasta el final 
ESCRITURA Y PODER EN CASTILLA DURANTE LA BAJA EDAD MEDIA: ESCRIBIR PARA EL GOBIERNO, ESCRIBIR PARA LA ADMINISTRACIÓN MAURICIO HERRERO JIMÉNEZ

del siglo xv ya cursivas. Corta vida la de la gótica documental, que se utilizará para redactar los documentos menos solemnes, pero que va a jugar un papel fundamental y que explicará la aparición de la escritura precortesana y cortesana, que en los manuales de Paleografía siempre se ha mantenido que eran evolución natural de la escritura de albalaes y que en la actualidad no es fácil de explicar ni de admitir.

La escritura gótica documental es una evolución de la pregótica y se emplea a partir de 1230 en la cancillería regia, tras la unificación de los reinos de Castilla y León, para escribir los diplomas menos solemnes hasta que, ya en el reinado de Alfonso X, con una mayor producción documental, se hace predominante la escritura cursiva, que surge por el simple hecho de un trazado más rápido por esa producción diplomática más voluminosa. Para escribir más deprisa hay que unir las letras, desarrollar astiles y caídos e incurvarlos y cerrarlos para ganar tiempo. Tiempo más necesario en la oficina regia de expedición de documentos, en la cancillería real, de ahí que sea en esta donde la cursivización de la escritura se adelanta y desde los años sesenta se hace exclusiva, única en los diplomas menos solemnes.

La escritura de albalaes evolucionó en la cancillería real (es, de hecho, una escritura cancilleresca, aunque se utilice para la escrituración de los documentos privados) desde las cursivas góticas del siglo XIII ${ }^{62}$.

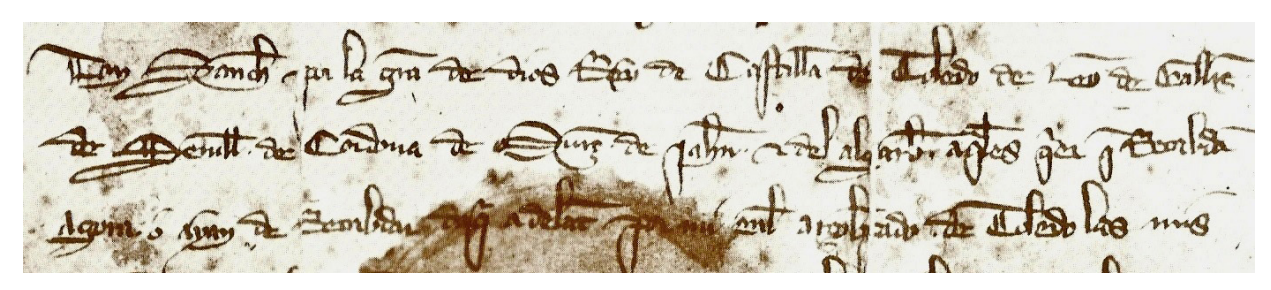

FIgura 4. 1289, junio, 23. Fragmento de provisión real de Sancho IV ${ }^{63}$. Escritua de albalaes.

Pero es una escritura que resulta un tanto rígida, acomodada al esplendor del imperio, y no se encurva lo suficiente para ser trazada al ritmo que la administración cada vez más burocrática requería. Fue una escritura que en la cancillería de fines del reinado de Alfonso X y sobre todo en la de Sancho IV, que hizo de ella una seńa de identidad, se empleó para los documentos que no eran de aparato. Pero la rigidez mencionada la lleva a su extinción en la propia cancillería. La artificialidad de la escritura, de astiles y caídos desproporcionados con respecto al cuerpo de las letras, muy pequeńo, la duplicación de estos y el predominio de la verticalidad de los trazos hacían de la letra una escritura no operativa para una administración que a mediados del siglo xiv exigía una letra más rápida. La escritura que la cancillería del príncipe Sancho hizo más suya en el tiempo en que se rebeló contra su padre no podría dar respuesta a las necesidades de una administración

62 Sobre la escritura de albalaes véase: Casado Quintanilla, Blas. «Notas sobre la llamada letra de albalaes». Espacio, Tiempo y Forma. Serie III, Historia Medieval, 1996, vol. 9, pp. 327-345.

63 Imagen tomada de Millares Carlo, Agustín, con la colaboración de Ruiz Asencio, José Manuel, Tratado de Paleografía española, II. Láminas, documento 210. 
ESCRITURA Y PODER EN CASTILLA DURANTE LA BAJA EDAD MEDIA: ESCRIBIR PARA EL GOBIERNO, ESCRIBIR PARA LA ADMINISTRACIÓN MAURICIO HERRERO JIMÉNEZ

en evolución y que, como afirma Rodríguez de Diego, en toda Europa vive en las décadas frontera del siglo XIII al XIV y hasta la mitad de esta centuria un movimiento perfeccionador de los órganos de gobierno y administración ${ }^{64}$, que en Castilla empiezan a ser visibles con las reformas administradoras de Alfonso $\mathrm{XI}^{65}$. Administración que precisa de tipos diplomáticos nuevos y de una escritura que se adecue a una mayor demanda diplomática. Y esa no será la letra de albalaes, ni siquiera la del siglo XIv, trazada con un ángulo menos agudo que en la centuria anterior. La escritura de albalaes a mediados del siglo xIV será una escritura muerta porque es imposible trazarla con un ángulo más abierto que permitiera la evolución a la escritura precortesana, que tiene su origen en escrituras góticas cursivas del siglo XIII y primera mitad del xIV que se trazaban fuera de la cancillería real, por notarios que escribían documentos de negocios de derecho privado, que, por lo demás, también emplearán, aunque en menor medida, la escritura de la cancillería.

A mediados del siglo xiv la escritura de los diplomas de cancillería y la de los documentos notariales comenzaba a ser la misma. Una escritura gótica cursiva precortesana que es la respuesta que encuentran los órganos de gobierno y el notariado a la necesidad de una letra cada vez más rápida en un ambiente cada vez más papelero. La precortesana es una realidad gráfica en la cancillería de Alfonso XI a finales de la cuarta década del XIV, momento en que para redactar los documentos solemnes en la oficina regia se empezó a usar la gótica redonda. En la cancillería de Pedro I la precortesana será la letra empleada de forma exclusiva para los documentos menos solemnes y la gótica redonda será la letra de los documentos solemnes ${ }^{66}$.

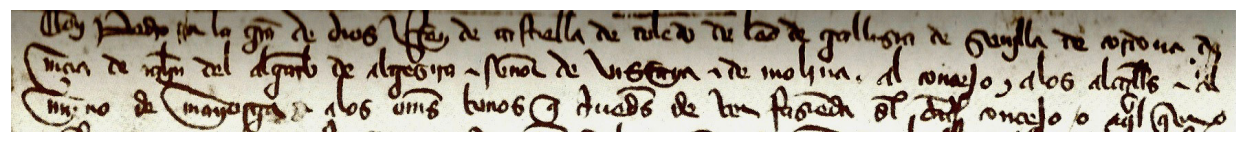

Figura 5. 1363, marzo, 17. Fragmento de provisión real de Pedro I ${ }^{67}$. Escritura precortesana.

¿Por qué la letra precortesana? Porque el ángulo con que se escribe permite que los caídos de las letras puedan incurvarse, trazando las líneas que bajan con un giro a la derecha, para buscar la línea del renglón e incluso el astil de la letra siguiente y formar nexos y ligaduras que aceleran la escrituración. Es la consecuencia de un trazado rápido porque no se hace necesario levantar la pluma tanto como lo exigía la letra de albalaes.

La precortesana es una escritura de transición, pero que se desarrollará y hará más rápida a medida que la administración genera más y más documentos como resultado de la asuncion de un número mayor de competencias. Al final de la Baja Edad Media, la especialización y separación de los negocios y órganos de gobierno y justicia que se inaugura con la dinastía Trastámara dará lugar a dos tipos de escritura que tienen su origen

64 Rodríguez de Diego, «Evolución histórica del expediente», p. 480.

65 Moxó, Salvador de. "La sociedad política castellana en la época de Alfonso XI». Hispania, 1975, vol. 35, n. ${ }^{\circ}$ extra 6, pp. 187-326, especialmente p. 276.

66 Sobre la escritura precortesana véase CASAdo Quintanilla, Blas. «Nuevas aportaciones sobre la "letra cortesana", nombre dado a este tipo gráfico por la corte de Castilla». Espacio, Tiempo y Forma. Serie III, Historia Medieval, 2014, vol. 27, pp. 193-209.

${ }_{67}$ Imagen tomada de Millares Carlo, Tratado de Paleografía española, III. Láminas, doc. 285. 
ESCRITURA Y PODER EN CASTILLA DURANTE LA BAJA EDAD MEDIA: ESCRIBIR PARA EL GOBIERNO, ESCRIBIR PARA LA ADMINISTRACIÓN

en la precortesana. Cada una de ellas se empleará predominantemente en un ámbito: la cortesana será más la escritura de los órganos de gobierno ${ }^{68}$; la procesada (antes que la procesal y esta después) será la empleada para los escritos de la justicia. Y de ello se dieron cuenta sus contemporáneos, que en el reinado de los Reyes Católicos las pusieron esos nombres: cortesana y procesal, y las adjetivaron, a la primera como buena letra y a la segunda, la procesada, que es una evolución de aquella, como mala, por ser más suelta, más rápida, como requiere la mayor escrituración de la justicia, con expedientes procesales perfectamente fijados, resultado de una mayor y más completa tecnificación.

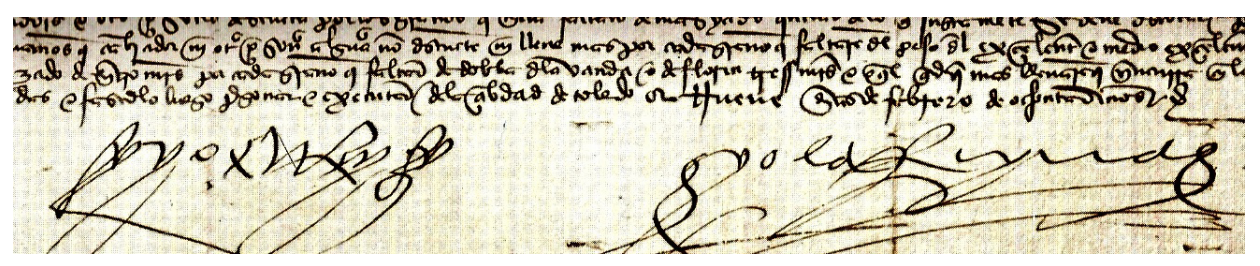

Figura 6. 1480, febrero, 9. Fragmento de carta misiva de los Reyes Católicos ${ }^{69}$. Escritura cortesana.

La cortesana evoluciona a partir de la precortesana en el primer cuarto del siglo xV y a finales de la centuria es una letra ya canonizada, que se empleará en todos los órganos, todos los ámbitos, todos los espacios de Castilla. No tiene fronteras de ningún tipo hasta los años cuarenta del siglo Xvi, cuando es sustituida por la procesal. Y no las tuvo porque fue una letra que podía ser escrita con una gran rapidez, perfecta no solo para la actividad administrativa y procedimental que requieren las dos vías de resolución de negocios inauguradas con la dinastía Trastámara: la de expediente y la procesal, sino también las necesidades papeleras de los negocios privados. Todo requería una escritura muy rápida, que se logra llevando al límite las espirales formadas por los caídos de las letras que giran en sentido dextrógiro para fundirse con los astiles de las letras y las líneas generales de abreviación, agrandando el módulo de los caracteres y comprimiéndolos dentro de las palabras, cada vez más juntas las unas a las otras, y acrecentando los nexos y alterando la forma originaria de cada una de las letras si la mayor rapidez de trazado lo requiere.

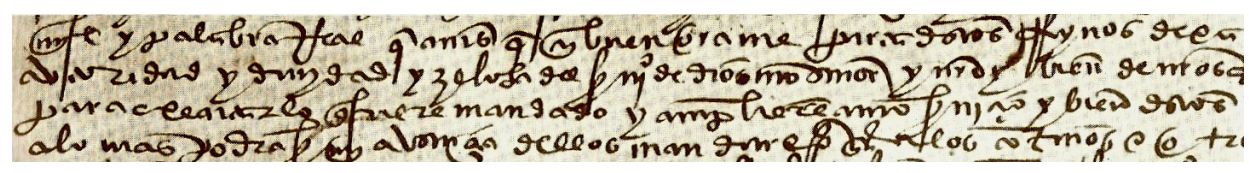

Figura 7. 1520, mayo, 7. Fragmento de provisión de Carlos I ${ }^{70}$. Escritura cortesana.

Es una escritura la cortesana asimilada y querida también para la comunicación privada. Los nobles y los reyes no dudaron en emplearla en el siglo xv para sus asuntos

68 Véase Galende Díaz, Juan Carlos y Salamanca López, Manuel Joaquín. Una escritura para la modernidad: la letra cortesana. Cagliari: Istituto di Storia dell'Europa Mediterranea, 2012.

69 Imagen tomada de Millares Carlo, Tratado de Paleografía española, III. Láminas, doc. 292.

70 Imagen tomada de Millares Carlo, Tratado de Paleografía española, III. Láminas, doc. 383. 
ESCRITURA Y PODER EN CASTILLA DURANTE LA BAJA EDAD MEDIA: ESCRIBIR PARA EL GOBIERNO, ESCRIBIR PARA LA ADMINISTRACIÓN MAURICIO HERRERO JIMÉNEZ

particulares, los mercaderes para sus negocios comerciales y de cambios y los amantes para sus quehaceres de amor. La cortesana es la escritura común, está en el imaginario gráfico de los administrados, los que podían y sabían leer y escribir, y los administradores. Imaginario común que desaparece con la aparición en escena de la procesada y la humanística.

La procesada no deja de ser una escritura cortesana trazada de forma rapidísima y muy suelta, lo que acentúa los rasgos definidores de esta: se alargan más los trazos iniciales y finales de las letras que hacen de nexo y se agranda más el módulo. Y esto será así hasta que aparece en escena, en la segunda y tercera década del siglo XvI, la letra procesal, una escritura distinta, que es preciso cuestionarse si, como se afirma tradicionalmente, evoluciona desde la procesada y la cortesana o, como pudo muy bien ocurrir, tiene otros orígenes.

\section{Conclusión}

Los cambios de la escritura en la Corona de Castilla en los siglos bajomedievales que hemos referido permiten reconocer la transformación del conjunto de la administración de la monarquía castellana, que ya en el siglo XIII reclama para sí no solo esa administración sino también el gobierno del reino. Desde esa centuria hasta el reinado de los Reyes Católicos la escritura nos permite reconocer, una vez armada la estructura administrativa en los años medios del xIv, que en la evolución de sus formas alfabéticas se explican, porque es consecuencia de ello, las transformaciones de las acciones de gobierno ejercido por una administración con una mayor capacidad de actuación, más continua y más eficiente, generadora también de un número mayor de documentos escritos con una letra imaginada para la administración de una monarquía que entre los siglos XIII y XV fue poco a poco afirmándose, robusteciéndose, acumulando poder, y en ello la escritura jugó sus bazas. La escritura, y el empleo e iluminación de los signos y las letras y miniaturas, que jugaron un papel esencial para visibilizar (con otros artificios) el poder ${ }^{71}$.

\section{REFERENCIAS BIBLIOGRÁFICAS}

Calleja Puerta, Miguel y Sanz Fuentes, M. a Josefa (coords.). Las escrituras góticas desde 1250 hasta la imprenta. Oviedo: Universidad de Oviedo, 2010.

Camino Martínez, M. ${ }^{a}$ Carmen del. "La escritura documental en el reinado de Fernando III». Archivo Hispalense, 1994, vol. 77, pp. 83-88.

Casado Quintanilla, Blas. «Notas sobre la llamada letra de albalaes». Espacio, Tiempo y Forma. Serie III, Historia Medieval, 1996, vol. 9, pp. 327-345.

Casado Quintanilla, Blas. «Nuevas aportaciones sobre la "letra cortesana", nombre dado a este tipo gráfico por la corte de Castilla». Espacio, Tiempo y Forma. Serie III, Historia Medieval, 2014, vol. 27, pp. 193-209.

71 Sanz Fuentes, M. ${ }^{a}$ Josefa, «Poder y escritura en la monarquía castellana de la Baja Edad Media. Sus manifestaciones». En Martín López, M. ${ }^{a}$ Encarnación y García Lobo, Vicente (coords.). Las inscripciones góticas. II Coloquio Internacional de Epigrafía Medieval. León del 11 al 15 de septiembre de 2006. León, 2010, pp. 145-159, especialmente 154-159. 
ESCRITURA Y PODER EN CASTILLA DURANTE LA BAJA EDAD MEDIA: ESCRIBIR PARA EL GOBIERNO, ESCRIBIR PARA LA ADMINISTRACIÓN MAURICIO HERRERO JIMÉNEZ

Cunnca Muñoz, Paloma. «La escritura gótica cursiva castellana: su desarrollo histórico». En GALENDE Díaz, Juan Carlos (dir.). III Jornadas Científicas sobre Documentación en época de los Reyes Católicos. Madrid: Universidad Complutense, 2004, pp. 23-34.

Dios, Salustiano de. «El ejercicio de la gracia regia en Castilla entre 1250 y 1530. Los inicios del Consejo de la Cámara». Anuario de Historia del Derecho Español, 1990, vol. 60, pp. 323-352.

Dios, Salustiano de. El Consejo Real de Castilla (1385-1522). Madrid: Centro de Estudios Políticos y Constitucionales, 1982.

Dios, Salustiano de. Gracia, merced y patronazgo real. La Cámara de Castilla entre 1474-1530. Madrid: Centro de Estudios Políticos y Constitucionales, 1993.

Fernández Ordóñez, Inés. "La lengua de los documentos del rey: del latín a las lenguas vernáculas en las cancillerías regias de la Península Ibérica». En Martínez Sopena, Pascual y Rodríguez, Ana (eds.). La construcción medieval de la memoria regia. Valencia: Universidad de Valencia, 2011, pp. 323-362.

Floriano Cumbreño, Antonio C. Curso general de Paleografía y Paleografía y Diplomática españolas. Oviedo: Universidad de Oviedo, 1946.

Galende Díaz, Juan Carlos y Salamanca López, Manuel Joaquín. Una escritura para la modernidad: la letra cortesana. Cagliari: Istituto di Storia dell'Europa Mediterranea, 2012.

García Díaz, Isabel y Montalbán Jiménez, Juan Antonio. «El uso del papel en Castilla durante la Baja Edad Media». En Actas del VI Congreso Nacional Historia del papel en España. Buñol (Valencia), 23-25, junio de 2005. Valencia: Conselleria de Cultura, Educació i Esport, 2005, pp. 399-418.

García Oro, José. «Clasificación y tipología documental». En Riesco Terrero, Ángel (ed.). Introducción a la Paleografía y a la Diplomática General. Madrid: Síntesis, 1999, pp. 207-231.

Gelb, Ignace J. Historia de la escritura. Madrid: Alianza Editorial, 1991.

Gimeno BlaY, Francisco M. «Conservar la memoria, representar la sociedad». SIGNO. Revista de Historia de la Cultura Escrita, 2001, vol. 8, pp. 275-293.

González, Julio. Reinado y diplomas de Fernando III. I. Estudio. Córdoba: Publicaciones del Monte de Piedad y Caja de Ahorros, 1980.

GonzÁlez Crespo, Esther. "Organización de la cancillería castellana en la primera mitad del siglo XIV». En la Espańa medieval, 1986, vol. 8, pp. 447-470.

Hajnal, Istvan. L'enseignement de l'écriture aux universités médiévales. Deuxième édition revue, corrigée et augmentée des manuscrits posthumes de l'auter, avec un album de facsimilés par Laszlo Mezey. Budapest: Maison d'Édition de l'Académie des Sciences de Hongrie, 1959.

Herrero Jiménez, Mauricio. «La vocación de paleógrafo de José Manuel Ruiz Asencio». En Herrero de la Fuente, Marta et ál. (coords.). Alma Littera. Estudios dedicados al Profesor José Manuel Ruiz Asencio. Valladolid: Universidad de Valladolid, 2014, pp. 317-325.

Herrero Jiménez, Mauricio. «La escritura hispano-gótica: la escritura gótica documental castellana (siglos XiII-XVII)». En Galende Díaz, Juan Carlos; Cabezas Fontanilla, Susana y Ávila Seone, Nicolás (coords.). Paleografía y escritura hispánica. Madrid: Síntesis, 2016, pp. 171-199.

Herrero Jiménez, Mauricio, «El valor de los documentos reales en los procesos de la Real Chancillería de Valladolid». Espacio, Tiempo y Forma. Serie III, Historia Medieval, 2018, vol. 31, pp. 403-430.

KLEINE, Marina. La cancillería real castellana durante el reinado de Alfonso X (1252-1284): una aproximación prosopográfica (Tesis doctoral), Sevilla, 2012.

KLEINE, Marina. «Los orígenes de la burocracia regia en Castilla: la especialización de los oficiales de Alfonso X y Sancho IV». e-Spania. Revue Interdisciplinaire d'Études Hispaniques Médiévales et Modernes, 2015, vol. 20, pp. 1-28. 
ESCRITURA Y PODER EN CASTILLA DURANTE LA BAJA EDAD MEDIA: ESCRIBIR PARA EL GOBIERNO, ESCRIBIR PARA LA ADMINISTRACIÓN MAURICIO HERRERO JIMÉNEZ

Las Siete Partidas del Sabio Rey Don Alfonso el IX [sic] con las variantes de más interés y con la glosa de Gregorio López; vertida al castellano y estensamente adicionada, con nuevas notas y comentarios y unas tablas sinópticas comparativas, sobre la legislación española, antigua y moderna, hasta su actual estado, por Ignacio Sanponts y Barba, Ramón Martí de Eixala y José Ferrer y Subirana. Barcelona: Imprenta de Antonio Bergnes, 1843-1844.

LLEDó, Emilio. El silencio de la escritura. 2. a ed. Madrid: Espasa, 1999.

López Gutiérrez, Antonio J. «La tradición documental en la cancillería de Alfonso X». Historia. Instituciones. Documentos, 1992, vol. 19, pp. 253-266.

López Gutiérrez, Antonio J. «La Cancillería de Fernando III, Rey de Castilla y León (12301253): notas para su estudio". Archivo Hispalense, 1994, vol. 77, pp. 71-82.

López Gutiérrez, Antonio J. «Registros y registradores en la Cancillería de Alfonso X». Estudis Castellonencs, 1994-1995, vol. 6, pp. 709-720.

López Gutiérrez, Antonio J. "Oficio y funciones de los escribanos en la cancillería de Alfonso X». Historia. Instituciones. Documentos, 2004, vol. 31, pp. 353-368.

López Gutiérrez, Antonio J. «La génesis documental en la Cancillería Real de Alfonso X». Documenta \& Instrumenta, 2016, vol. 14, pp. 77-116.

MacDonald, Robert A. «El cambio del latín al romance en la Cancillería real de Castilla». Anuario de Estudios Medievales, 1997, vol. 27, pp. 381-413.

Marín Martínez, Tomás y Ruiz Asencio, José Manuel. Paleografía y Diplomática. 5. a ed. Madrid: UNED, 1991, 2 vols.

Martín Prieto, Pablo. «Idea e imagen del rey en la diplomática medieval hispana: el valor de los preámbulos». Espacio, Tiempo y Forma. Serie III, Historia Medieval, 2016, vol. 29, pp. 453-496.

Mellado Rodríguez, Joaquín. «El fuero de Córdoba: edición crítica y traducción». Arbor, 2000, vol. 654, pp. 191-232.

Menant, François. "Las transformaciones de la escritura documental entre los siglos XII y XIII». Traducción de Pascual Martínez Sopena, revisada por Miguel Calleja Puerta. Edad Media. Revista de Historia, 2015, vol. 16, pp. 33-53.

Menéndez Pidal, Ramón. Orígenes del español. 6. a ed. Madrid: Espasa Calpe, 1968.

Millares Carlo, Agustín, con la colaboración de José Manuel Ruiz Asencio. Tratado de Paleografía española. Madrid: Espasa Calpe, 1983, 3 vols.

Millares Carlo, Agustín y Mantecón, José Ignacio. Álbum de Paleografía Hispanoamericana de los siglos XVI y XVII. I. México: Instituto Panamericano de Geografía e Historia, 1955.

Molina de la Torre, Francisco Javier. Corpus inscriptionum Hipaniae mediaevalium. 3. Valladolid (siglos $X-X V)$. [León]: Universidad de León, 2017.

Moxó, Salvador de. «La sociedad política castellana en la época de Alfonso XI». Hispania, 1975, vol. 35, n. ${ }^{\circ}$ extra 6, pp. 187-326.

Ostos Salcedo, Pilar. «La cancillería de Fernando III, Rey de Castilla (1217-1230): una aproximación». Archivo Hispalense, 1994, vol. 77, pp. 59-70.

Ostos Salcedo, Pilar y Sanz Fuentes, M. a Josefa. "Corona de Castilla. Documentación Real. Tipología (1250-1400)». En Diplomatique royale du Moyen Âge XIII'-XIV siècles. Porto: Faculdade de Letras, 1996, pp. 239-279.

Ostos Salcedo, Pilar. "Cancillería castellana y lengua vernácula: su proceso de consolidación». Espacio, Tiempo y Forma. Serie III, Historia Medieval, 2004, vol. 17, pp. 471-484.

Ostos Salcedo, Pilar. «Las escrituras góticas hispanas. Su bibliografía». En Calleja Puerta, Miguel y SAnz Fuentes, M. Josefa (coords.). Las escrituras góticas desde 1250 hasta la imprenta. Oviedo: Universidad de Oviedo, 2010, pp. 17-49. 
ESCRITURA Y PODER EN CASTILLA DURANTE LA BAJA EDAD MEDIA: ESCRIBIR PARA EL GOBIERNO, ESCRIBIR PARA LA ADMINISTRACIÓN MAURICIO HERRERO JIMÉNEZ

Rodríguez, Ana. «La preciosa transmisión. Memoria y curia regia en Castilla en la primera mitad del siglo XiII». En Martínez Sopena, Pascual y Rodríguez, Ana (eds.). La construcción medieval de la memoria regia. Valencia: Universidad de Valencia, 2011, pp. 293-322.

Rodríguez De Diego, José Luis. «Evolución histórica del expediente». Anuario de Historia del Derecho Español, 1998, vol. LXVIII, pp. 475-490.

Rodríguez de Diego, José Luis. "El archivo real de la Corona de Castilla (XIII-Xv)». En SARAsA SÁNCHEZ, Esteban (coord.). Monarquía, crónicas, archivos y cancillerías en los reinos hispanocristianos: siglo XIII-XV. Zaragoza: Institución Fernando el Católico, 2014, pp. 277-308.

Romero Tallafigo, Manuel; Rodríguez Liáñez, Laureano y Sánchez González, Antonio. Arte de leer escrituras antiguas. Paleografía de lectura. 3. ${ }^{a}$ ed. Huelva: Universidad de Huelva, 2003.

Ruiz García, Elisa. «El poder de la escritura y la escritura del poder». En Nieto Soria, José Manuel (dir.). Orígenes de la Monarquia Hispánica. Propaganda y legitimación (ca. 1400-1520). Madrid: Dykinson, 1999, pp. 275-313.

Sánchez Belda, Luis. La Cancillería castellana durante el reinado de Sancho IV (1284-1295). Madrid: Instituto Nacional de Estudios Jurídicos, 1951.

Sánchez Prieto, Ana Belén y Domínguez Aparicio, Jesús. «Las escrituras góticas». En Riesco Terrero, Ángel (ed.). Introducción a la Paleografía y a la Diplomática general. Madrid: Síntesis, 2000, pp. 111-147.

Sanz Fuentes, M. a Josefa. "Cancillería y cultura en la Castilla de los siglos XIV y XV». En Gualdo, G. Cancelleria e cultura nel Medio Evo. Comunicazioni presentate nelle giornate di studio della Commissione. Stoccarda, 20-30 agosto 1985. Città del Vaticano: Archivio Segreto Vaticano, 1990, pp. 187-199.

Sanz Fuentes, M. a Josefa. "Tipología documental de la Baja Edad Media castellana. Documentación real». En Archivistica. Estudios Básicos. Sevilla: Diputación Provincial de Sevilla, 1981, pp. 239-256.

Sanz Fuentes, M. a Josefa, "Poder y escritura en la monarquía castellana de la Baja Edad Media. Sus manifestaciones». En Martín López, M.a Encarnación y García Lobo, Vicente (coords.). Las inscripciones góticas. II Coloquio Internacional de Epigrafía Medieval. León del 11 al 15 de septiembre de 2006. León, 2010, pp. 145-159.

Sanz Fuentes, M. a Josefa. «La escritura gótica documental en la Corona de Castilla». En CALlejA Puerta, Miguel y Sanz Fuentes, M. a Josefa (coords.). Las escrituras góticas desde 1250 hasta la imprenta. Oviedo: Universidad de Oviedo, 2010, pp. 107-126.

Sierra Macarrón, Leonor. "La escritura y el poder: el aumento de la producción escrita en Castilla y León (siglos X-XIII)». SIGNO. Revista de Historia de la Cultura Escrita, 2001, vol. 8, pp. 249-274.

Stone, Lawrence. «Literacy and Education in England, 1640-1900». Past and Present, 1969, vol. 42, pp. 65-96.

Torres Sanz, David. La administración central castellana en la Baja Edad Media. Valladolid: Universidad de Valladolid, 1982. 